\title{
Report on intussusception in channel catfish Ictalurus punctatus (Rafinesque, 1818) from commercial farms in Mexico: A case study
}

\author{
ISIDRO O. MONTELONGO-ALFARO, JAIME L. RABAGO-CASTRO*, JESUS GENARO \\ SANCHEZ-MARTINEZ*, FLAVIANO BENAVIDES-GONZALEZ* AND NED IVAN DE LA \\ CRUZ-HERNANDEZ* \\ Universidad Tecnologica del Mar de Tamaulipas Bicentenario, La Pesca, Soto La Marina, Tamaulipas, Mexico \\ *Facultad de Medicina Veterinariay Zootecnia, Universidad Autonoma de Tamaulipas, Mexico \\ e-mail: jrabago@uat.edu.mx
}

\begin{abstract}
Intussusception is a rare condition in fish, mainly reported from Asian countries and it is considered an emergent disease in China. This is the first report on intussusception case in channel catfish Ictalurus punctatus, cultured in floating cages in Mexico. Fishes were sampled during an outbreak with daily mortalities above $1.14 \%$. Necropsy revealed intestinal intussusception, pale liver and hemorrhagic mesentery. Bacteriological analyses showed presence of Aeromonas sp. in internal organs and it is suggested that the presence of Aeromonas sp. is probably responsible for the observed condition.
\end{abstract}

Keywords: Aeromonas, Bacterial toxins, Channel catfish, Intussusception

Intussusception is a rare condition in humans and other mammals (Alvarez et al., 2000; Castro-Medina et al., 2015), which can be defined as the inversion (invagination) of one intestine portion within another (Byrne et al., 2005). In most cases, intussusception occurs in the same direction of peristalsis (Lideo et al., 2010), probably due to an increment in peristalsis, abscesses or enteric tumors (Okamoto et al., 2007); however, the cause of this condition in fish is not clear. Intussusception results in the obstruction to the passage of intestinal contents, vascular compression, edema and eventually ischemic necrosis (Castro-Medina et al., 2015). Fish intussusception has been reported mainly in cultured fish species like tilapia Orechromis spp. and channel catfish Ictalurus punctatus (Gaunt et al., 2007; Liu et al., 2008; Rey et al., 2009; Cao et al., 2016) and it is considered as an emerging disease in the latter (Seafood Watch, 2017). A correlation of this condition with bacterial infection (Vazquez-Pineiros et al., 2010; Wang et al., 2011) or exposure to type E botulin toxin (Gaunt et al., 2007; Khoo et al., 2011) has also been reported. Most intussusception cases reported are from Chinese catfish farms (Liu et al., 2008; Geng et al., 2010; Cao et al., 2016) where it is a frequent condition that results in mortalities, thus representing an important production risk (Liu et al., 2008). Bacteria such as Aeromonas hydrophila, Hafnia alvei, Pseudomonas fluorescens and Stenotrophomonas maltophilia have been isolated from the above incedences, suggesting an infectious origin, but other factors as contaminated feed or incorrect use of feed additives are also suggested (Cao et al., 2016). An early case of intestinal intussusception in channel catfish was reported in fish experimentally exposed to saponified castor oil (Tucker et al., 1986). Durborow and Hanson (1988) reported presence of Aeromonas spp. in channel catfish fingerlings with severed intestine, suggesting intussusception among the possible etiologies. Intussusception has also been reported in outbreaks caused by Edwardsiella ictaluri in the catfish Ameiurus nebulosus, which also presented red and white mottling in the liver (Iwanowicz et al., 2006). All these observations suggest that intussusception may be associated to toxins or bacterial infections. Channel catfish is an important fish species cultured in Mexico, with the state of Tamaulipas as the main supplier of catfish fingerlings for production farms, providing $61 \%$ of the channel catfish broodstock in Mexico and producing 50\% of the catfish for national consumption (Lara-Rivera et al., 2015).

The case took place in a catfish farm located in Tamaulipas, Mexico. Catfish were stocked at $15 \mathrm{~cm}$ length and reared in floating cages $\left(7 \mathrm{~m}^{3}\right) @ 250$ fish $\mathrm{m}^{-3}$. Fish were fed with commercial extruded feed (Bagre engorda Purina $^{\circledR} \# 4$, minimum protein $32 \%$, minimum fat $3.5 \%$, maximun fiber $7 \%$ ). Towards final phase of production, dead or moribund fishes were found floating in water surface, with a daily mortality rate of $1.14 \%$. Floating cages with the highest mortalities were sampled and necropsies were carried out in six fish (mean weight 729.2 $\pm 64.1 \mathrm{~g}$ ). Fishes appeared normal externally. Internal lesions 
were noticed in one fish, which showed a $15 \mathrm{~cm}$ long intussusception in the distal portion of the intestine (Fig. 1) in the direction of peristalsis; with pale liver and a swollen and hemorrhagic spleen (Fig. 1). Obstruction to blood flow was also noticed in the proximal part of the invaginated intestine, which exhibited a thicker diameter as well as venous congestion on the invaginated portion (Fig. 1). Parasitological analyses showed only a moderate level infection of the monogenean (Ligictaluridus floridanus) on gills (Jimenez et al., 2010). Samples of liver, intestine, trunk kidney and gills were taken for bacteriological (Castro Escarpulli et al., 2003) and histopathological investigations (Bernet et al., 1999; Rosenthal et al., 2013). Results of bacteriology showed presence of Aeromonas sp. in liver and kidney. Histopathology revealed distension and fatty degeneration in liver (Fig. 2) which could be attributed to metabolic causes (Rosenthal et al., 2013); lumen obliteration, tissue compression and mucous hyperplasia in intestine indicating intussusception (Fig. 3) as well as

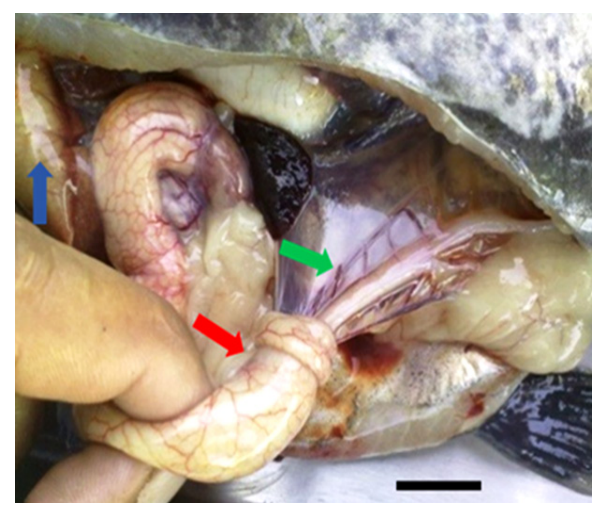

Fig. 1. Catfish, Ictalurus punctatus. Pale liver $(\rightarrow)$, congestion of blood vessels $(\rightarrow)$; intussusception $(\rightarrow)$. Bar $1.0 \mathrm{~cm}$ (Photograph by I. O.)

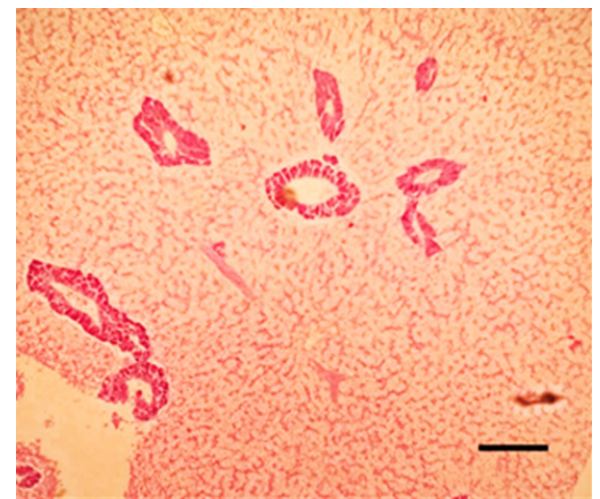

Fig. 2. Histological section of liver of Ictalurus punctatus showing hepatic cell distension and fatty degeneration $(\mathrm{H} \& \mathrm{E}) . \mathrm{Bar}=20 \mu \mathrm{m}$

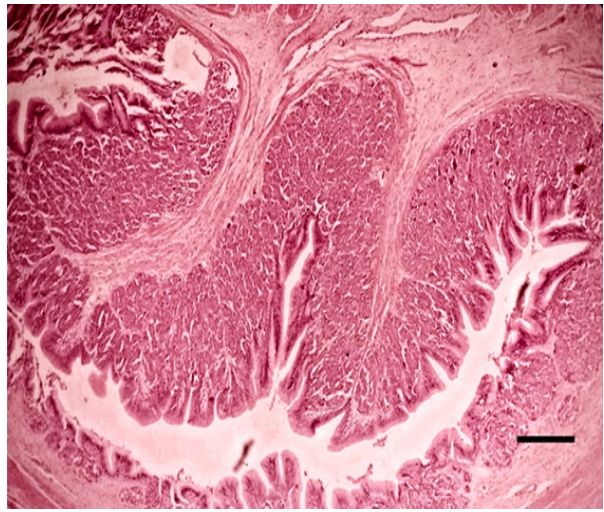

Fig. 3. Histological section of intestine of Ictalurus punctatus presenting intestinal intussusception. Lumen obliteration, tissue compression and mucous hyperplasia are observed $(\mathrm{H} \& \mathrm{E}) \mathrm{Bar}=100 \mu \mathrm{m}$

a moderate inflammatory reaction and blood precipitates in trunk kidney (Fig. 4). Physicochemical parameters of the lake water recorded were also analysed during the study and the values recorded were: Temperature $-19^{\circ} \mathrm{C}$; $\mathrm{pH}$ - 7.5; dissolved oxygen - $6.04 \mathrm{mg} \mathrm{l}^{-1}$, total ammonia - 0; Alkalinity - $324 \mathrm{mg} \mathrm{CaCO}_{3} \mathrm{l}^{-1}$ and hardness - $297.6 \mathrm{mg}$ $\mathrm{CaCO}_{3} \mathrm{I}^{-1}$. Water temperature at sampling time was $19^{\circ} \mathrm{C}$ (Table 1), which is consistent with Durborow et al. (1988) who documented intestinal alterations in cultured channel catfish when temperatures ranged from 12 to $19^{\circ} \mathrm{C}$.

The presence of pathogenic bacteria is related to stress in fish (Marques et al., 2016) and isolation of S. maltophilia has been reported in cases of intussusception in channel catfish (Geng et al., 2010; Wang et al., 2011). Aeromonas spp. in catfish (Durborow and Hanson, 1988; Liu et al., 2008; Tong et al., 2009), tilapia Oreochromis spp. (Vazquez-Pineiros, et al., 2010) and the red-bellied

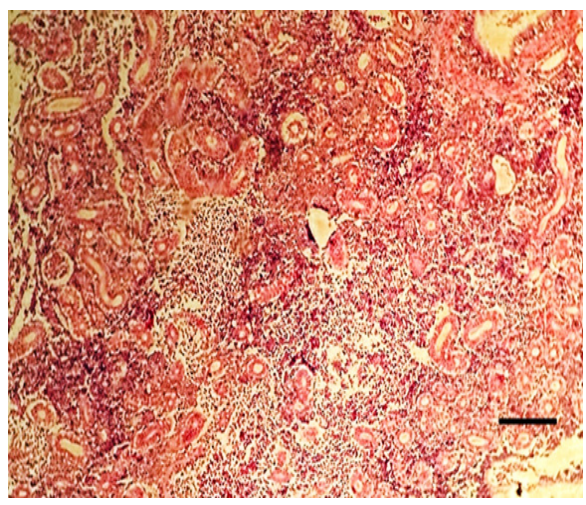

Fig. 4. Histological section of trunk kidney of Ictalurus punctatus showing desquamation, congestion, moderate inflammatory reaction and precipitates from blood $(\mathrm{H} \& \mathrm{E})$. Bar $=20 \mu \mathrm{m}$ 
Table 1. Water physicochemical parameters in the lake recorded during the study

\begin{tabular}{llllll}
\hline $\mathrm{pH}$ & $\begin{array}{l}\text { Total ammonia } \\
\left(\mathrm{mg} \mathrm{l}^{-1}\right)\end{array}$ & $\begin{array}{l}\text { Alkalinity }\left(\mathrm{CaCO}_{3}\right) \\
\left(\mathrm{mg} \mathrm{l}^{-1}\right)\end{array}$ & $\begin{array}{l}\text { Hardness }\left(\mathrm{CaCO}_{3}\right) \\
\left(\mathrm{mg} \mathrm{l}^{-1}\right)\end{array}$ & $\begin{array}{l}\text { Temperature } \\
{ }^{\circ} \mathrm{C}\end{array}$ & $\begin{array}{l}\text { Dissolved oxygen } \\
\left(\mathrm{mg} \mathrm{l}^{-1}\right)\end{array}$ \\
\hline 7.5 & 0.0 & $324 \pm$ & $297.6 \pm$ & $19 \pm$ & $6.04 \pm$ \\
\hline
\end{tabular}

pacu Piaractus brachypomus (Rodriguez et al., 2005; Rey et al., 2009) has been commonly associated with intussusception. In the same way, Liu et al. (2008) reported association between $P$. fluorencens and intussusception during experimental infection in channel catfish, highlighting that this may not be the only probable cause of intussusception.

There are some studies reporting use of antibiotics as treatment to intussusception in channel catfish (Liu et al., 2008; Tong et al., 2009; Geng et al., 2010). However, treatment for intussusception should include an integral approach considering other possible causes like toxins or stress problems induced by inadequate management. Correction of these problems would help to reduce the use of chemicals in fish culture, decreasing environmental pollution (Cabello and Godfrey, 2016). In the present case of intussusception, though the primary cause of the syndrome could not be established, it is construed that it is related to the presence of Aeromonas sp. and/or its toxins, as it has been already reported that the virulence factor of bacterial pathogens probably cause intussusception (Cao et al., 2016). Further research is required to elucidate the exact causes of intussusception as well as to take the necessary measures for its prevention. To our knowledge, this is the first report of intussusception in commercial fish culture in Mexico.

\section{References}

Alvarez, E. F., Moreno, R. S., Hernandez, T. R., Alvarez, A. D. C. F., Sanchez, D. E. and Benavides, R. B. 2000. Intususcepcion: una causa poco frecuente de obstruccion intestinal. Cir. Gral., 22: 216-220.

Byrne, A. T., Goeghegan, T., Govender, P., Lyburn, I. D., Colhoun, E. and Torreggiani, W. C. 2005. The imaging of intussusception. Clin. Radiol., 60: 39-46.

Cabello, F. C. and Godfrey, H. P. 2016. Even therapeutic antimicrobial use in animal husbandry may generate environmental hazards to human health. Environ. Microbiol., 18: 311-313.

Castro Escarpulli, G., Aguilera-Arreola, M. G., HernandezRodriguez, C. H., Arteaga-Garibay, R. I., CarmonaMartinez, A. A., Perez-Valdespino, A., Giono-Cerezo, S., Figueras-Salvat, M. J. and Aparicio Ozores, G. 2003. La identificación genética de Aeromonas, una realidad y una necesidad para la microbiología diagnostica. Bioquim., 28: $11-18$

Castro Medina, C. A., Jimenez, H. C. and Cardona, S. M. 2015. Intususcepcion idiopatica en el adulto: presentacion de caso clinico, diagnostico y tratamiento. Rev. Colomb. Gastroenterol., 30: 474-478.

Cao, H., He, S., Li, Y., Yang, Y. and Ai, X. 2016. Hafnia alvei: a pathogen causing Infectious Intussusception Syndrome (IIS) in farmed channel catfish Ictalurus punctatus. Israeli J. Aquac., Bamidgeh, IJA 68.2016.1305. http://cmsadmin. atp.co.il/Content_siamb/editor/68.2016.1305.Yang.pdf (Accessed: 30 August 2017).

Durborow, R. M. and Hanson, L. 1988. Severed intestine in channel catfish. J. Wildl. Dis., 24: 146-149.

Gaunt, P. S., Kalb, S. R. and Barr, J. R. 2007. Detection of botulinum type $\mathrm{E}$ toxin in channel catfish with visceral toxicosis syndrome using catfish bioassay and endopep mass spectrometry. J. Vet. Diagn. Invest., 9: 349-354.

Geng, Y., Wang, K., Chen, D., Huang, X., He, M. and Yin, Z. 2010. Stenotrophomonas maltophilia, an emerging opportunist pathogen for cultured channel catfish, Ictalurus punctatus, in China. Aquaculture, 308: 132-135.

Iwanowicz, L. R., Griffin, A. R., Cartwright, D. D. and Blazer, V. S. 2006. Mortality and pathology in brown bullheads Amieurus nebulosus associated with a spontaneous Edwardsiella ictaluri outbreak under tank culture conditions. Dis. Aquat. Org., 70: 219-225.

Jimenez-Guzman, F., De la Paz-Tijerina, Ma., Ramirez-Almaraz, C. and Salazar-Torres, D. 2010. Tecnicas de Parasitologia Aplicadas a la Sanidad Acuicola. Centro de Investigacion de Desarrollo Biotecnologico y Diagnostico S. A. de C. V. Mty, N. L. Mexico, 26 pp.

Khoo, L. H., Goodwin, A. E., Wise, D. J., Holmes, W. E., Hanson, L. A., Steadman, J. M. and Gaunt, P. S. 2011. The pathology associated with visceral toxicosis of catfish. $J$. Vet. Diagn. Invest., 23: 1217-1221.

Lideo, L., Mutinelli, F. and Milan, R. 2010. Pylorogastric intussusception in a Chihuahua puppy. A case report. J. Ultrasound, 13: 175-178.

Liu, J. Y., Yang, W. M., Li, A. H. and He, G. W. 2008. Preliminary study on the etiology of channel catfish intussusception disease. Acta Hydrobiol. Sin., 32: 824-831.

Lara-Rivera, A. L., Parra-Bracamonte, G. M., Sifuentes-Rincon, A. M., Gojon-Baez, H. H., Rodriguez-Gonzalez, H. and Montelongo-Alfaro, I. O. 2015. El bagre de canal (Ictalurus punctatus Rafinesque, 1818): estado actual y problematica en Mexico. Lat. Am. J. Aquat. Res., 43: 424-434.

Marques, D. S., Ferreira, D. A., Paiva, P. M., Napoleao, T. H., Araujo, J. M., Maciel Carvalho, E. V. and Coelho, L. C. 
2016. Impact of stress on Aeromonas diversity in tambaqui (Colossoma macropomum) and lectin level change towards a bacterial challenge. Environ. Technol., 1-20.

Okamoto, H. M., Itoh, M., Koiwa, M., Inagaki, M., Nadao, T., Kurosawa, T. and Taniyama, H. 2007. Intussusception of the spiral colon associated with fibroserous granulation in a heifer. Vet. Rec., 160(11): 376-378.

Rey, A., Verjan, N., Ferguson, H. W. and Iregui, C. 2009. Pathogenesis of Aeromonas hydrophila strain KJ99 infection and its extracellular products in two species of fish. Vet. Rec., 164: 493-499.

Rodriguez, M., Botero, E., Iregui, C. A. and Figueroa, J. 2005. Extraccion de productos extracelulares de Aeromonas hydrophila y sus efectos en tilapia roja (Oreochromis spp.) y cachama blanca (Piaractus brachypomus). Acta Biolo. Colomb., 10: 75-94.

Rosenthal, S., Sandoval, N., Gavidia, C. and Tabacchi, L. 2013. Frecuencia de lipidosis hepática en trucha arcoiris (Oncorhynchus mykiss) de fase juvenil en una piscigranja de la sierra central del Peru. Rev. Invest. Vet. Peru, 24: 118-124.
Seafood Watch 2017. Monterey Bay Aquarium. Channel Catfish Ictalurus punctatus. China ponds and net pens. Seafood Watch Consulting Researcher, 65 pp.

Tong, G. X., Li, X. Z., Wei, X. X., Wu, X. Q. and Lu, X. H. 2009. Identification and antibiotic sensitivity of pathogen of intussusception disease found in channel catfish Ictalurus punctatus. J. Dalian Fish. Univ., 475-481.

Tucker, C. S., Francis-Floyd, R. and Beleau, M. H. 1986. Acute toxicity of saponified castor oil to channel catfish, Ictalurus punctatus, under laboratory and field conditions. Bull. Environ. Contain. Toxicol., 37: 297-302.

Vasquez-Pineros, M. A., Rondon-Barragan, I. S, RestrepoBetancur, L. F. and Eslava-Mocha, P. R. 2010. Estudio clinico y hematologico de una infeccion experimental con Aeromonas hydrophila y Edwardsiella tarda en tilapia, Oreochromis sp. Rev. Orinoq., 14: 33-44.

Wang, K. Y., Deng, L. J., Huang, J. L., Fu, X., Chen, D. F., Geng, Y. and Huang, X. L. 2011. Study on the immunogencity of poly (D, L-lactide-co-glycolide) (PLGA) microspheres-encapsulated vaccine preparation against Stenotrophomonas maltophilia infection in channel catfish (Ictalurus punctatus). Afr. J. Biotechnol., 10: 2751. 